\title{
El fenómeno del canibalismo en las fuentes literarias grecorromanas: su mención en la mitología y la filosofía antigua*
}

\author{
Domingo F. Sanz \\ domingo.fsanz.edu@juntadeandalucia.es \\ Cannibalism in Latin-Greek sources: its references in mythology
and ancient philosophy
}

En este artículo se pretende analizar y comentar el mayor número posible de menciones al fenómeno del canibalismo existentes en la tradición literaria grecolatina. Tras repasar las fuentes, es posible distinguir las diferentes maneras en que esta tradición abordó dicho fenómeno y descubrir una intención común: partiendo de la mitología o la epopeya homérica, pasando por las distintas corrientes filosóficas y de pensamiento, empezaremos a comprobar cómo en muchas ocasiones se hace uso del concepto de canibalismo para definir negativamente al Otro, al distinto y/o al distante, inaugurando así un tópico que aún pervive.

Palabras clave: Canibalismo; literatura grecolatina; mitología; filosofía; Séneca; Ovidio.
This article tries to analyze and comment on the greater amount of references regarding the phenomenon of cannibalism that there exists in Greek and Latin literary tradition. After reviewing many of the sources, it is possible to distinguish the different ways in which this tradition approached such phenomenon and to discover a common intention: starting from the mythology or the Homeric epic, going through the different philosophical trends and schools of thought, we will begin to realize and conclude that in many occasions there is a use of the concept of cannibalism to negatively define «the other», the outcast or foreigner, opening thus a topic that still survives nowadays.

Key words: Cannibalism; Latin-Greek literature; mythology; philosophy; Seneca; Ovid.

* Este artículo se ha realizado en el marco del proyecto de investigación FFI-200806919-C02-01 FILO del CSIC y con el apoyo del grupo de investigación «Nicolaus Heinsius» (HUM 261) de la Universidad de Huelva. Estoy muy agradecido a los profesores Pedro Bádenas, Ana Pérez y Juan Antonio Estévez por sus sugerencias y correcciones, así como a mis anónimos revisores: sus aportaciones han sido muy valiosas. De todos ellos son los aciertos de este trabajo. 
El fenómeno del canibalismo ${ }^{1}$, uno de los mayores, si no el mayor tabú cultural, ha atraído desde siempre la curiosidad del ser humano, especialmente del hombre occidental - pero no solo, toda vez que esta práctica es asimismo rechazable en otros países y culturas-, como se puede comprobar sobre todo desde los siglos XVIII y XIX en la literatura y en el XX y comienzos del XXI también en el cine. La civilizada y ordenada mentalidad occidental ha relacionado dicho fenómeno o bien con culturas primitivas y salvajes, bárbaras en el sentido moderno del término, o bien con comportamientos perturbados o con situaciones de extrema necesidad.

En la bibliografía existente he observado que, en los capítulos dedicados a la Antigüedad grecolatina, las referencias se limitan generalmente a lugares comunes y pasajes muy conocidos, para dirigir inmediatamente la atención a culturas más lejanas en el espacio, pero más cercanas en el tiempo (las sociedades del Pacífico occidental o las de Mesoamérica, por ejemplo), o a episodios relacionados con guerras o accidentes (como el de los desdichados náufragos de La Medusa).

Como veremos, en la primera expresión artística escrita en lengua griega ya encontramos referencias al tema del canibalismo, asunto que en la Antigüedad es tratado de manera fragmentaria en las fuentes grecorromanas, y pasa de la mera mención del hecho de una manera, digamos, aséptica a una intencionalidad que busca influir en la mente del receptor. A veces sirven para medir el grado de barbarie de determinadas sociedades con las que la civilizada Grecia o la poderosa Roma entran en contacto; sin embargo, hay ocasiones en que encontramos pasajes en los que son los mismos civilizados miembros de sus sociedades quienes protagonizan infames episodios de canibalismo.

${ }^{1}$ Utilizaré el término «canibalismo», a saber, comer la carne de otro de la misma especie, aun siendo una palabra desconocida en época grecolatina, toda vez que empezó a utilizarse a partir del descubrimiento de América, al considerarla más exacta que «antropofagia»: por ejemplo, no juzgo el episodio de Polifemo o el de los lestrígones en la Odisea como ejemplos de canibalismo, aunque sí lo sean de antropofagia, pues los considero monstruos que devoran seres de otra especie, en este caso a los pobres compañeros de Odiseo; sin embargo, sí hay posibilidad de considerar que un ser como Saturno comete un acto de canibalismo, aunque no sea propiamente antropofagia, toda vez que a quien devora es a sus propios hijos, seres divinos. V. Burkert 1983, p. 130, quien considera, sin embargo, la aventura de Polifemo como «the oldest story of cannibalism in Greek literature». 
Como filólogo clásico, en este trabajo me he propuesto comenzar la recopilación de las fuentes grecolatinas que hacen algún tipo de mención de este fenómeno $\mathrm{y}$, en un segundo momento, ordenar de alguna manera ese fondo, según el campo del que proceda: ahora bien, debido al gran número de ejemplos, he limitado mi estudio a la mitología y la filosofía ${ }^{2}$.

1. La rica mitología griega contiene variados e importantes elementos que se pueden interpretar como episodios de canibalismo. El recuerdo de tiempos muy lejanos en los que el hombre viviría sometido al miedo a ser devorado por animales salvajes se refleja también de alguna manera en episodios antropófagos en la mitología y, por ende, en la literatura griega. La genealogía divina, por ejemplo, es vista por algunos como una sucesión de padres que devoran a sus hijos y de hijos que castran a sus padres ${ }^{3}$. Esta dramática ruleta que comienza con Urano, que oculta a sus vástagos en el amplio pecho de Gea, y continúa con Crono, que devora o engulle sistemáticamente a sus hijos una vez los engendra Rea, concluye con Zeus, quien, aconsejado por Gea y Urano, se traga a Metis, la cual — decía la profecíaengendraría después de Atenea a un varón que en el futuro reinaría sobre los dioses. De este modo, Metis no puede quedar encinta y la profecía queda inconclusa.

Si se considera este episodio como un acto de canibalismo, se podría entender también como un ejemplo de «endocanibalismo», un elemento inherente en otros casos que escapan a nuestro estudio: el hecho de devorar al otro tiene como consecuencia adquirir o asimilar las características de la

2 McGowan 1994, pp. 423-433, presenta una clasificación de cierto número de fuentes que mencionan el canibalismo en cuatro categorías: caníbal filosófico, exótico, mítico y político. Esta categorización agrupa bastantes ejemplos en los autores grecolatinos y coincide parcialmente con lo que expongo en mi artículo, aunque no es del todo completa.

3 «The genealogy of the Greek gods is a succession of devouring fathers and castrating sons that ends only with Zeus, who takes rather drastic precautions against filias rebellion. In Hesiod's version, he swallows his mate, Metis, to assimilate her potentially subversive female energy and appropiate the act of procreation for himself alone; in Homer's, he gains power through abortion, or rather abstinence, when, forewarned of the consequences, he refuses to mate with Tetis and father a son greater than himself» Kilgour 1990, p. 14. Los mitos de sucesión de los reyes divinos no son exclusivos de los griegos. Encontramos un interesante antecedente en la mitología hitita (de al menos ca. 1200 a. C.) en el que, además, hay un ejemplo de castración caníbal que no existe en la versión griega que nos ha transmitido Hesíodo (Fox 2009, p. 341). 
víctima. De este modo, Hesíodo, que afirma de Metis que es la más sabía entre los dioses y los hombres mortales (Th. 887), explica posteriormente que el hecho de tragarse a Metis le sirve a Zeus para que le aconsejara sobre el bien y el mal ${ }^{4}$. No acaba, por así decirlo, con su vida, no la encierra en el Tártaro, sino que se la traga y, con ello, adquiere sus habilidades intelectivas, haciéndolo definitivamente todopoderoso.

Sin embargo, hay quien puede considerar una confusión o error metodológico de base el hecho de dar a estos episodios la categoría de actos de canibalismo, toda vez que sus protagonistas no devoran a sus hijos o a sus potenciales rivales, sino que los engullen enteros como en una especie de encierro, quedando en situación de nonatos ${ }^{5}$. El léxico utilizado por Hesíodo parece dejarlo claro en el episodio de Urano, cuando dice que éste «iba ocultando» en el seno de Gea a los hijos que eran engendrados (Th. 157-158:

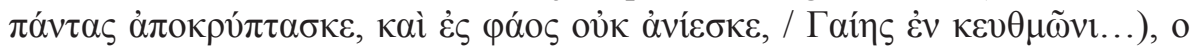

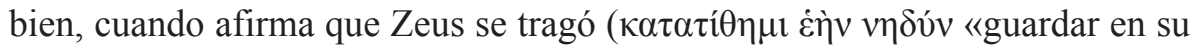
estómago» es la expresión utilizada por el poeta: Th. 890; 899) a Metis. Más ambiguo, sin embargo, se muestra cuando habla de Crono, al utilizar por tres

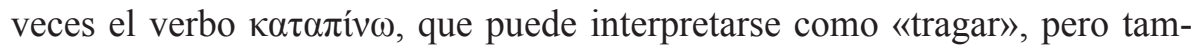
bién como «devorar» (Th. 459; 467; 473).

El canibalismo retrotrae al ser humano a la barbarie de los primeros

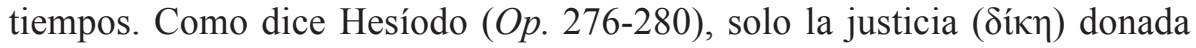
por Zeus nos hace diferentes de las bestias, que se caracterizan por devorarse las unas a las otras ${ }^{6}$. Sin embargo, en determinados episodios míticos, la justicia de Zeus aún no se ha impuesto, por lo que, en su todopoderoso y justo reinado, los actos de canibalismo no han desaparecido completamente ${ }^{7}$. Encontramos dos ejemplos muy parecidos de canibalismo por venganza: en primer lugar, Apolodoro (Epit. II 12-13) narra la terrible venganza de Atreo contra Tiestes; Atreo, que ocupaba el trono de Micenas y había desterrado a su hermano Tiestes, cuando se entera del adulterio que comete su esposa con éste, manda llamarlo. Fingiendo una reconciliación, le prepara un banquete que consiste en la carne de los hijos del propio Tiestes tras sacrificarlos en

${ }^{4}$ Hes, Th. 889-900. Según West 1997, p. 405 (citando a Onians 1951, p. 489, n.1) «connects the manner of Zeus' assimilation of Mĩ $\iota \varsigma$, putting her in his belly, with the idea of a prophetic spirit in the belly, as claimed by Euricles (sch. Ar., V., 1014; sch. Pl., Sph. 252c)».

${ }_{5}$ Agradezco a mi anónimo corrector el apunte.

${ }^{6}$ Véase asimismo Renehan 1981, pp. 254-256.

${ }^{7}$ Burkert 1983, pp. 103-107. 
el altar de Zeus. Cuando Tiestes termina de comer, Atreo le muestra las extremidades de los asesinados. Ovidio (Met. VI 424-674) ${ }^{8}$, por su parte, nos narra otro ejemplo de maldad mayúscula en los banquetes de Procne y Filomela: Tereo, esposo de Procne, viola a su cuñada Filomela. En venganza por tan terrible acto, ambas traman uno aún más atroz. Matan al niño Itis, hijo de Procne y Tereo, le cortan la cabeza, lo cocinan y condimentan. Ovidio detalla cómo una parte es hervida, mientras otra es destinada al asador. Se lo dan de comer a Tereo y, finalmente, le presentan la cabeza del niño muerto. Otro ejemplo de canibalismo como respuesta a una violación incestuosa lo encontramos en Partenio (XIII): Clímeno se enamora de su hija, Harpálice, se la arrebata a su prometido y escapa con ella a Argos. La muchacha, que siente que está siendo ultrajada por su padre, trama su venganza. Mata a su hermano pequeño, lo descuartiza y se lo sirve a su padre durante un banquete ritual ${ }^{9}$.

Asimismo, son característicos los intentos de probar la sabiduría de los dioses buscando engañarlos mediante actos de antropofagia. Así actúa Tántalo, abuelo de Atreo y Tiestes, cuando asesina a su hijo Pélope, lo trocea y se lo da de comer a los dioses (Ou., Met. VI 404-411; Hyg., Fab. LXXXIII). Por su parte, Ovidio (Met. I 162-243) cuenta cómo es Júpiter quien recuerda el infame banquete de Licaón (foeda Lycaoniae referens conuiuia mensae I $165)^{10}$, y cómo este último sacrifica a un prisionero moloso y lo cocina. El poeta también detalla, como en el episodio de Procne y Filomela, que cuece una parte y asa otra (226-229) ${ }^{11}$.

En la epopeya homérica encontramos numerosas escenas de combate en las que se describe la violencia con un detalle y un dramatismo, me atrevería a decir, cinematográfico. El héroe homérico, en especial Aquiles, dentro de este ambiente bélico se ve arrastrado por unos sentimientos arrebatadores

${ }^{8}$ El mismo episodio se menciona en Apollod. III 14.8; Hyg., Fab. XLV.

9 Menos conocido es el mito de Demifonte, que transmite Higinio (Astr. II 40.3), quien cuenta que un noble llamado Mastusio, en venganza, asesina a las hijas del rey Demifonte, mezcla su sangre con vino y se la hace beber al propio soberano.

${ }^{10}$ También es Licaón quien prueba a Zeus en Hyg., Astr. II 4. Por su parte, en Eratosth., Cat. VIII; Apollod. III 8.1; Hyg., Fab. CLXXVI y Nonn., D. XVIII 20-24 son los hijos de Licaón los que intentan probar a Zeus, mezclando carne humana con la de un sacrifício. Para otras variantes sobre este episodio, v. Ruiz de Elvira 1995, pp. 444-445.

${ }^{11}$ Sobre este detalle de asar una parte de la carne del sacrificio y de cocer otra, v. Burkert 1983, p. 89, n. 29. 
difícilmente controlables y estos elementos se conjugan en la batalla final. Tras una lucha a muerte entre los dos campeones de los bandos, griego y troyano, Aquiles asesta el golpe mortal sobre su archienemigo troyano y se desencadena en el líder de los mirmidones un odio salvaje, superior al que haya podido sentir jamás un ser humano. Ese feroz sentimiento para con el odiado Héctor le lleva a despreciar las más mínimas reglas de honor: que los perros despedacen su cuerpo insepulto. El héroe troyano le suplica, pero

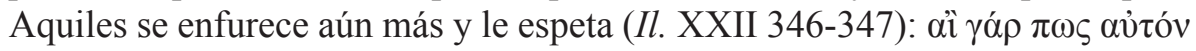

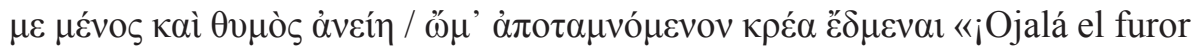
y el coraje me empujaran a cortar y comerme crudas tus carnes!». ${ }^{12}$

Desea su destrucción y aniquilamiento, hacerlo desaparecer devorándolo crudo. Sin embargo, Aquiles no se va a entregar al odio caníbal: con que los perros y las aves de rapiña destrocen su cuerpo es suficiente. Pero aunque no llega a cumplir lo dicho, aunque no traspasa las barreras, sus palabras retratan claramente la fiereza de Aquiles ${ }^{13}$. Este brutal lenguaje lo vemos también en un pasaje más: cuando Hécuba muestra su odio visceral hacia Aquiles, asesino de su hijo (XXIV 212-214) ${ }^{14}$. Como vemos, estos ejemplos son en realidad desiderata, en ningún momento hay posibilidad de que esos fuertes sentimientos acaben en un acto de canibalismo, pero sirven al poeta para mostrar, como pinceladas en un retrato, el extremado grado al que puede llegar la pasión de sus personajes ${ }^{15}$.

${ }^{12}$ Salvo que se indique lo contrario, aquí y en lo sucesivo se ofrece una traducción propia de los textos.

${ }^{13}$ No me resisto a comentar que 2.800 años después en un sucedáneo de la epopeya griega como es el cómic de superhéroes americano encontramos por casualidad una escena muy parecida: después de un combate apocalíptico, un superhéroe, Hulk, caracterizado por su salvaje fuerza sobrehumana, devora el cuerpo de su enemigo derrotado como culminación de la victoria (The Ultimates, vol. II, 4, Cómics Forum, 2003). Al menos Aquiles no llega a cumplir su inconcebible deseo.

${ }^{14} \mathrm{Cf}$. el potencial acto de antropofagia que encontramos en las palabras que Zeus dirige a Hera, cuando afirma que ésta solo calmaría su ira hacia los troyanos si devorara ( $\beta \varepsilon \beta \rho \omega ́ \theta 01 \varsigma)$ crudo a Príamo, a los hijos de éste y a los demás troyanos (IV 34-36).

${ }^{15}$ Cf. X., $H G$ III 3.6, donde Jenofonte refiere que un tal Cinadón, que conspiraba contra el rey Agesilao, odiaba tanto a los espartiatas que se los comería crudos, y X., An. IV 8.14:

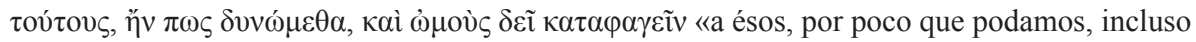
crudos hay que comérselos». El propio Jenofonte anima a sus compañeros de expedición a combatir a los colcos, quienes son el último obstáculo para alcanzar el ansiado Mar Negro. De nuevo la desesperación que han provocado tantas y tantas penalidades a través del imperio persa, lleva al ateniense a esta arenga: incluso si hace falta, habrá que comerse crudos a los enemigos que se les enfrentan. 
En la épica arcaica fragmentaria (schol. Il. V 126 [fr. 9 Bernabé]) hallamos un testimonio de canibalismo bastante significativo y que traspasa la línea roja que no hemos visto en Homero: el de Anfiarao. Éste odiaba a Tideo por haber sido él junto con Polinices el promotor del asalto a Tebas. Para evitar que Atenea salvase a Tideo, al que le había prometido la inmortalidad, y que yacía moribundo tras haber sido herido mortalmente por Melanipo, Anfiarao medita una acción que provoque el rechazo de la diosa y se abstenga de curarlo: Anfiarao mata a Melanipo y le lleva la cabeza cortada a Tideo quien la abre y le sorbe de manera frenética los sesos. Atenea no soporta este hecho y deja que Tideo mue$\mathrm{ra}^{16}$. El hecho de que la diosa que castiga la acción sea Atenea es, en mi opinión, sintomático, como quiera que es una diosa que se caracteriza por favorecer las causas justas. De este modo, queda claro que los dioses rechazan absolutamente manifestaciones de este tipo que van más allá del orden y las convenciones.

También hallamos en la épica de Virgilio una breve referencia al canibalismo como venganza en clara relación con el mencionado banquete de Tiestes. Cuando Dido ve las naves de Eneas abandonar Cartago, se apodera de ella la locura y la agitación. A gritos, desde la atalaya, se pregunta de manera retórica qué acciones podría haber cometido para vengar su amor traicionado: despedazar el cuerpo de su amado o pasar por las armas a sus compañeros y al mismísimo Ascanio, el hijo de Eneas, para servirlo a continuación en la mesa de su padre (En. IV 601-602 non ipsum absumere ferro / Ascanium patriisque epulandum ponere mensis?).

En los pasajes literarios que recogen de alguna manera la celebración de ritos dionisíacos, también se mencionan actos de canibalismo. Así, según Bonnechère 1994, p. 211, la teoría denominada «de la fertilidad» vería que la tragedia euripídea de Las bacantes «laisserait transparaitre les survivances d'antiques sacrifices humains et de cannibalisme». Así, por ejemplo, en los momentos finales de la tragedia, Eurípides (1184 y 1241-1242), con la locura de Ágave, convierte el sacrificio realizado «into potential cannibalism» cuando invita a Cadmo y sus amigos a un festín que «mercifully, never takes place» ${ }^{17}$. Sin embargo, en otras fuentes encontramos a mujeres que sufren el

${ }^{16}$ Este episodio lo encontramos citado también en schol. Lyc. 1066; schol. Pind., Nem. X 7, 12; y con variantes en Apollod. III 6.8; Stat., Theb. VIII 717-767 (v. Ruiz de Elvira 1995, p. 151).

${ }^{17}$ Henrichs 2000, p. 188. Dodds opina con total convencimiento que en los rituales orgiásticos griegos se daban los actos de hacer pedazos a un animal ( $\sigma \pi \alpha \rho \alpha \gamma \mu$ ó $)$ y de devorarlo

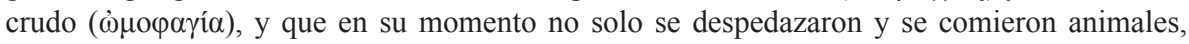


castigo de Dioniso y acaban despedazando y devorando a sus hijos, como las Miniades, que, enloquecidas, acaban con Hípaso, hijo de una de ellas, Leucipe en concreto, o las mujeres de Argos, que terminan practicando el canibalismo con sus hijos de pecho. Asimismo, los básaros, pueblo de origen tracio que sufre la ira de Zeus por su desprecio a los dioses, experimentaron una especie de furor orgiástico que terminó en sacrificios humanos; sin embargo, esa locura les hizo arrojarse los unos contra los otros, lanzándose dentelladas y repartiéndose trozos de carne ensangrentada. Solo al exterminar la generación que descendía de los primeros que se dedicaron a estos sacrificios, cesaron estas prácticas caníbales ${ }^{18}$. De la misma manera, el tesalio Erisicton sufre la ira divina, en este caso de Deméter, cuando aquél se empeñó en cortar una encina en un bosque consagrado a la diosa. Ésta manda al Hambre que castigue a Erisicton con un espantoso apetito que nunca queda saciado. Primero, el pobre desgraciado acaba con toda su hacienda, luego intenta vender a su propia hija y, al final, se ve obligado al «autocanibalismo», o sea, acaba devorándose a sí mismo ${ }^{19}$.

2. En gran parte de los relatos mitológicos mencionados, el canibalismo es un instrumento de venganza en un contexto caracterizado por el dominio de pasiones desenfrenadas y la ausencia de justicia. Por su parte, un movimiento religioso como el orfismo o una escuela de pensamiento presocrática

sino que «existió una vez una forma más potente, por ser más terrible, de este sacramento, a saber, la de despedazar, y quizá comer, a Dios en forma de hombre; y que la historia de Penteo es, en parte, un reflejo de aquel acto» (Dodds 1999, p. 259).

${ }^{18}$ Sobre las Miniades, v. Plu., Moralia 299e, donde las hijas de Minias «dicen que se vieron presas de la locura y estaban deseosas de carne humana, por lo que sortearon a sus

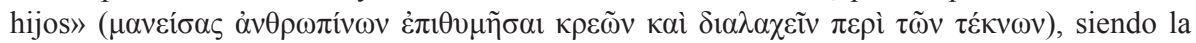

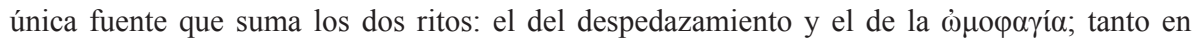
Ant. Lib X, como en Ael., VH III 42 no se dice que tras el despedazamiento de Hípaso se

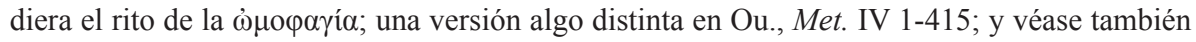
Ruiz de Elvira 1995, p. 451; sobre las mujeres de Argos, Apollod. III 5.2; sobre los básaros de Tracia, Porph., Abst. II 8: hay una pintura en vaso que reproduce a un tracio devorando a un niño (Bonnechère 1994, p. 238, n. 44). V. asimismo Henrichs 1984, pp. 210-211.

${ }^{19}$ Ou., Met. VIII 738-878 y Ruiz de Elvira 1995, p. 456. En su catálogo de glotones, Ateneo (X 415c-d) transmite un fragmento de Janto de Lidia (FGH 765 F 18) en el que encontramos el grotesco caso del rey Cambles de Lidia que llega a devorar a su propia esposa tras despedazarla. Se supone que lo hizo de manera inconsciente, pues al descubrir al día siguiente lo ocurrido (de manera muy gráfica, Ateneo dice que Cambles tiene la mano de aquélla en su boca), y al hacerse público además, éste se quitó la vida. 
como el pitagorismo consideran este fenómeno no solo un elemento inherente del estadio salvaje del ser humano, sino también una consecuencia lógica y extrema de su creencia en la inmortalidad del alma, que se reencarna una y otra vez. Asimismo, el canibalismo no es un fenómeno unívoco, pues presenta diferencias conceptuales que podemos observar en los escritos de las escuelas de pensamiento de la Antigüedad; éstas se debaten entre la aceptación, cuando la necesidad disculpa dicha práctica, o el rechazo absoluto a las prácticas antropofágicas, consideradas algo monstruoso, impropio de la naturaleza humana.

Según la cosmología órfica, al principio, el ser humano se hallaba en el grado de la animalidad y el canibalismo sin que lo rigiera ley alguna, sino la del más fuerte (Orph., Fr. 641) ${ }^{20}$; sin embargo, un dios se apiada del género humano y envía a las diosas portadoras de las leyes, que acaban con el «canibalismo ilegal» e introducen la agricultura. El hecho de abandonar el consumo de carne y empezar el de productos de la tierra conlleva la civilización de la sociedad. Testimonios posteriores ${ }^{21}$ convierten a Orfeo, como portador de la cultura, en una especie de héroe civilizador que aparta al hombre del sacrificio animal y del consumo de carne ${ }^{22}$. El modo de vida de los seguidores de Orfeo, por tanto, aconsejaba apartarse de comer carne, debido a su impureza, y no manchar de sangre los altares ${ }^{23}$. Por consiguiente, la doctrina

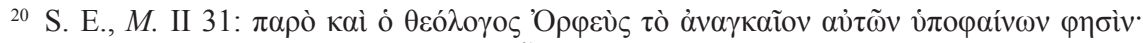

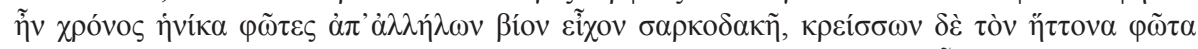

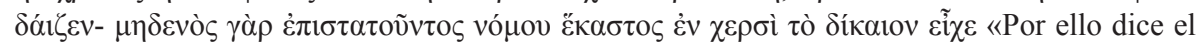
teólogo Orfeo, haciendo ver su necesidad: "Hubo un tiempo en que los hombres eran carnívoros / y se devoraban entre sí, y el más fuerte daba muerte al débil”, pues cuando no regía ninguna ley cada uno defendía sus derechos con la fuerza...» (trad. de J. Bergua Cavero). Cf. Moralia 1124d, donde Plutarco carga contra el epicureísmo. Según él, el epicúreo Colotes cree que el hecho de apartarse de las leyes y costumbres, y del gobierno de las ciudades, cosa que les ha proporcionado una gran seguridad y tranquilidad, alejándolas de la confusión, empujará a los hombres a una vida propia de bestias y al canibalismo ( $\theta \eta \rho i ́ \omega v$ ßíov $\beta 1 \omega \sigma o ́ \mu \varepsilon \theta \alpha$

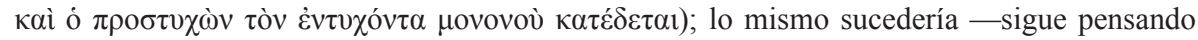
Colotes - si el ser humano abandonase las enseñanzas de Parménides, Sócrates, Heráclito o Platón. Sin embargo, Plutarco opina que aquél habla sin atenerse a la justicia y la verdad (ov̉

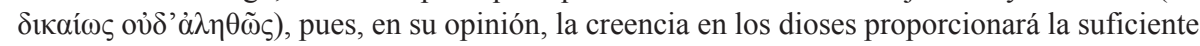
protección frente a ese estado animalístico y caníbal.

${ }^{21}$ Ar., Ra. 1032; Hor., Ars 391-392; Them, Or. XXX 349b-c; Porph., Abst. II 36.

${ }_{22}^{2}$ S. E., M. II 32; véase también Nestle 2010, p. 54.

${ }^{23}$ Pl., Lg. 782c. 
órfica consideraba que el canibalismo estaba «au coeur même des rituels de la cité, laquelle traite de Barbare quiconque se prête à l'anthropophagie» (Bonnechère 1994, p. 232). Como dice Jiménez San Cristóbal 2009, p. 788, «la insistencia en ingerir solo alimentos ö $\psi v \chi \alpha$ y abstenerse de los $\check{\varepsilon} \mu \psi v \chi \alpha$ está estrechamente relacionada con la teoría de la metempsicosis». Por ello, solo el consumo de alimentos ö $\psi v \chi \alpha$ evita al hombre caer en el canibalismo.

Por su parte, la doctrina pitagórica, en relación a su creencia en la transmigración de las almas, a saber, que se reencarnaban una y otra vez en otros seres $^{24}$, asumía como una de sus características la dieta vegetariana, por ello Pitágoras (D. L. VI 73 [VI 41]) advertía a su audiencia de que evitara las Thyestis ... mensis y le aconsejaba que adoptara una vida vegetariana ${ }^{25}$. El respeto de los pitagóricos por los animales es consecuente con la creencia de que éstos «participan de un alma que se reencarna sucesivamente y está presente en cualquier cuerpo vivo» (Casadesús Bordoy 2009, p. 1070).

Asimismo, Empédocles de Agrigento, debido a su creencia en la metempsicosis, consideraba, junto con los pitagóricos, que existía una especie de vínculo entre los dioses, los hombres y los seres irracionales, un espíritu único a modo de alma que se propagaría por el mundo entero. Empédocles, de modo semejante a los órficos, creía que, en una primera edad, los hombres vivían regidos por Afrodita —o Cipris-; además, los sacrificios eran incruentos, y derramar la sangre sobre los altares y devorar animales sacrificados eran los actos más abominables (31 B $128 \mathrm{D}-\mathrm{K})$, pues, en un primer momento, las fieras salvajes y los hombres vivían en armonía (31 B 130 D-K). Pero esa armonía desaparece con la Discordia o el Odio, principio disgregador y maligno, que ha empujado al hombre a matar animales y a consumir carne ${ }^{26}$. Así que el hecho de matar animales y alimentarse de su

${ }^{24}$ V., por ejemplo, la anécdota narrada por Jenófanes (21 B 7 D-K en D.L. VIII 36).

${ }^{25}$ Kilgour 1990, p. 128. Algunos fragmentos conservados de cómicos antiguos ridiculizaban los tabúes alimentarios que caracterizaban el modo de vida de los seguidores de estas doctrinas. Así, algunas personas, llevando al extremo la prohibición de comer carne humana, se abstenían de comer peces de alta mar, pues pensaban que éstos se alimentaban de los cadáveres de los náufragos. V., por ejemplo, Antiph., Fr. 127 K-A (en Ath. VII 303f-304a); Archestr., Shell. 154. 13-20 (en Ath. IV 163c; VII 310b-c). Para otros ejemplos, v. Bernabé 2009b, pp. 1232-1233.

2631 B 115 D-K. Megino 2009, p. 1117 (v. también pp. 1111-1112). La poesía órfica posterior (¿Onomácrito, época helenística?; v. especialmente Bernabé 2009a, pp. 591-607, que señala que las primeras referencias al mito ya configurado que sobreviven son neoplatónicas a partir del texto de las Rapsodias órficas, y que tal vez ya en el siglo VI a. C. se habían fundado 
carne conllevaba un pecado de injusticia e impiedad, pues, en suma, ese consumo constituiría un acto de canibalismo incluso entre parientes ${ }^{27}$.

El orfismo y el pitagorismo ${ }^{28}$, y por ende Empédocles mismo, prohibían también consumir ciertos alimentos considerados impuros, como por ejemplo las habas, toda vez que, siguiendo la lógica de la reencarnación de las almas, aquéllas podían contener «las almas de nuestros padres, de tal modo que comerlas supone un ejercicio de canibalismo» ${ }^{29}$.

También en Platón hallamos referencias - aunque escasas - al acto caníbal $^{30}$. En la República, Platón considera al tirano un caníbal que «baña su

ritos dionisíacos que hacían referencia a ello) explica con un relato mitológico el origen de la maldad en el ser humano, cuando los Titanes atraparon al niño Dioniso, lo trocearon, lo cocieron, lo asaron y se lo comieron. Zeus en castigo los fulminó con su rayo, y del humo de sus restos surgió la raza humana (Orph., Fr. 320; v. también Dodds 1999, pp. 151-153). Por tanto, esta culpa heredada por la raza de los hombres tiene su base, en este caso, en la acción más horripilante que se puede cometer, el canibalismo. También Plutarco menciona este episodio que simboliza el comportamiento del ser humano con los animales, seres inocentes (Moralia 996c).

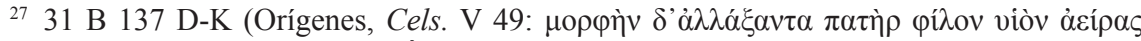

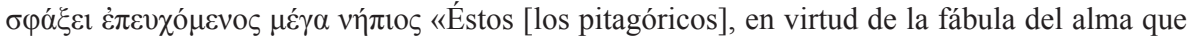
muta de cuerpos, se abstienen de los seres animados y [dicen que] alguien... levantando a su hijo / lo degüella haciendo una plegaria, el gran insensato...» (trad. de Ernesto La Croce); v. asimismo 31 B 136 D-K (S. E., M. IX 127). Según Bonnechère 1994, p. 232, todo sacrificio de víctimas animales, que no eran otras que difuntos reencarnados, se convertía «immanquablement au sacrifice humain et, pire encore, au cannibalisme». Cf. Plu., Moralia 996b, donde dice que Empédocles afirma «que las almas están encadenadas a cuerpos mortales para

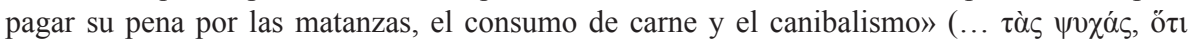

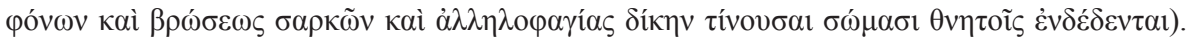
Más adelante (Moralia 997d-998a), aunque no dice expresamente que sigue las enseñanzas de Empédocles, Plutarco sí parece defender de algún modo la teoría de la metempsicosis.

${ }_{28}^{28}$ D. L. VIII 34 opina que es un precepto pitagórico.

${ }^{29}$ Megino 2009, p. 1138. En un verso órfico (Orph., Fr. 648; cf. Emp. 31 B 141 D-K:

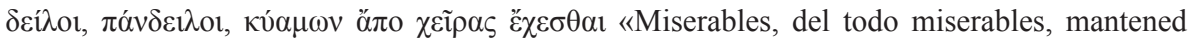
las manos / apartadas de las habas» [trad. de Ernesto La Croce]) se dice: «Igual es comer habas que las cabezas de los padres»; aunque Gelio (IV 11.9-10), al comentar el pasaje de Empédocles, opina que las «habas» pueden simbolizar más bien los testículos (cf. D. L. VIII 34, donde, citando a Aristóteles, explica que Pitágoras prohibía las habas, entre otras razones, por ser semejantes a los genitales). Véase Burkert 1983, p. 285, esp. n. 51, y Iuu. XV 170-174. Del mismo modo hay que interpretar la prohibición por parte de Empédocles de consumir hojas de laurel (31 B 140 D-K en Plu., Moralia 646 d), al constituir esta planta un lugar de migración privilegiado para el alma (31 B 127 D-K en El., Nat. anim. XII 7).

${ }^{30}$ Permítaseme señalar que su discípulo Aristóteles (EN VII 5 [1148b]) se limita a mencionar algunos casos de canibalismo desde un punto de vista etnográfico y médico. De este 
lengua y su boca» con la sangre de sus conciudadanos, en una especie de canibalismo social (VIII 16 [565e-566a]) ${ }^{31}$. Asimismo, al final de su obra, Platón, en su más clara conexión entre tiranía y canibalismo ${ }^{32}$, vuelve a insistir en el mito de Er en que la vida del tirano estaba destinada, entre otros crímenes, a devorar a sus propios hijos (X 16 [619b]) $)^{33}$.

Las motivaciones de las escuelas cínica y estoica para tratar el fenómeno del canibalismo son diferentes. Los cínicos, por ejemplo, se enfrentan a los convencionalismos de la sociedad que les ha tocado vivir y aceptan transgredir todas las prohibiciones existentes, especialmente las que conciernen al sexo y

modo, entre las disposiciones que considera brutales o morbosas, Aristóteles expone ciertos casos de canibalismo, por así decir, patológico, como el de la mujer que abría el vientre a otras mujeres encinta para devorar sus fetos, o la costumbre de algunos pueblos salvajes del Ponto que no solo comen carne cruda, sino también humana, o los que se comen niños en los banquetes. Además, distingue como disposiciones propias de locos o enfermos episodios que, sin duda, circularían de boca en boca, como el del hombre que sacrificó y devoró a su propia madre o el del esclavo que se comió el hígado de un compañero.

31 Sobre la imagen del tirano sediento de sangre, véase S., Ant. 201-202, donde, en su primer monólogo, Creonte acusa metafóricamente a Polinices de actuar a la manera de un ca-

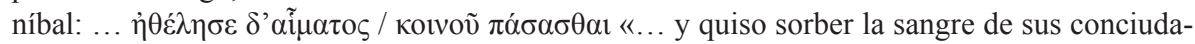

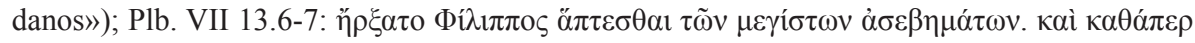

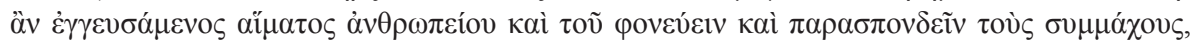

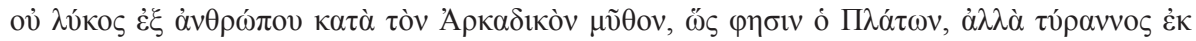

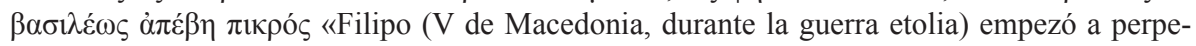
trar las impiedades más monstruosas; y como uno que ha probado sangre humana, que ha asesinado, que ha hecho traición a sus aliados, se convirtió no ya en lobo, de hombre que era, según la fábula de la Arcadia narrada por Platón, sino que de rey se transformó en el tirano más terrible» (trad. de Manuel Balasch Recort). Cf. en las fuentes latinas Sen., Cl. I 12. 1 y Ben. VII 19. 8 (más general); [Sen.] Oct. 243; los versos que circulaban contra Tiberio (Suet., Tib. LIX 1) o las palabras que dirige César contra Pompeyo (Luc. I 327-331).

${ }^{32}$ Hook 2005, pp. 23-24. Para mostrar la extrema crueldad a la que llegó otro tirano, en este caso Fálaris de Agrigento, Clearco (DSA III fr. 61, citado en Ath. IX 396e) menciona que, en los banquetes, solía probar la carne de bebés lactantes. Agradezco el apunte a mi anónimo corrector.

${ }^{33}$ Cf. lo contrario en Ar., Eq. 1131-1140, donde el poeta presenta a Demos como un antro-

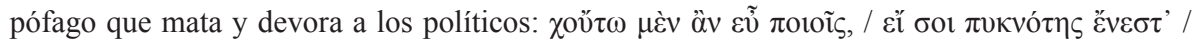

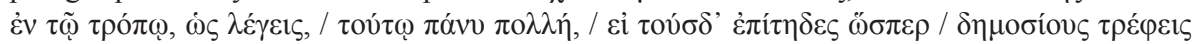

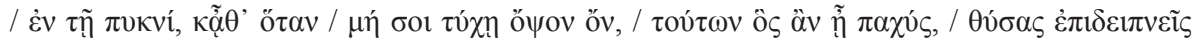
«Haces con esto muy bien / si de verdad una astucia / en el carácter, cual dices, / tuyo existe grande: / si a ésos con plena conciencia / cual víctimas del estado / en la Pnix crías y cuando / ves que no te queda carne, / de entre ellos al que está gordo / matas y te comes» (trad. de Francisco R. Adrados). 
a la alimentación. Así, Diógenes Laercio (VI 73) dice que Diógenes, el fundador de la secta de los cínicos, además de admitir entre otras cosas la unión con mujeres fuera del matrimonio o robar en los templos, defiende que es aceptable comer carne de cualquier animal, por lo que no es un sacrilegio alimentarse de carne humana, lo cual sucede en otras culturas. A este pensamiento habría que sumar también el razonamiento cínico de que todas las cosas están unas en otras y de que participan entre sí, por lo que el acto caníbal es inevitable, ya que la carne está en el pan y el pan lo está en las hierbas y en todos los demás cuerpos a través de unos ocultos poros por donde se introducen las partículas y se funden en forma de vapor ${ }^{34}$; parece ser que en el Tiestes, tragedia atribuida a Diógenes, se abordaba este espinoso tema ${ }^{35}$. Ésta y otras obras trágicas que se le atribuyen a Diógenes - apenas títulos o escasas referencias - , servirían, desde la visión distorsionada y crítica del cínico, para ejemplificar modos de vida, como el incesto y, de algún modo, el parricidio caníbal, no aceptables o, incluso, considerados pecaminosos por la sociedad en la que vive, pero que no lo serían desde su punto de vista.

Asimismo, la escuela estoica no se opone al canibalismo. Según su doctrina, el curso de la naturaleza estaba ordenado por una especie de Providencia benefactora. El conjunto, hasta en sus más pequeños detalles, estaba destinado a asegurar ciertos fines por medios naturales, fines que se hallan en la vida del hombre ${ }^{36}$. De este modo, igual que se acepta que hay animales cuya existencia tiene como propósito la alimentación del hombre, no es rechazable que el hombre se alimente de la carne de otros hombres, hecho reprobado por convención social (Zeno Stoic. fr. 254 Arnim. V. infra Thphl. Ant., Autol. III 5). Diógenes Laercio en su biografía sobre Zenón (VII 121) también menciona que el fundador del estocismo defiende el consumo de carne humana, aunque introduce un matiz: en situaciones de necesidad

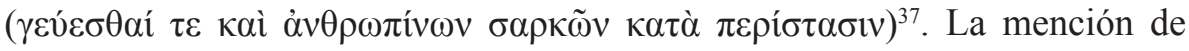

${ }^{34}$ Esta concepción de que todo está en todo, mezclado de alguna manera, surge con Anaxágoras; sin embargo, el epicúreo Lucrecio la rechaza completamente (Lucr. I 875).

${ }_{35}$ Diog., Fr. 88. 1d, en D. L. VI 73.

${ }^{36}$ Russell 1995, p. 297.

37 Sobre la interpretación del matiz introducido por Diógenes Laercio, v. Hook 2005, pp. 35-36. Entre esas especiales circunstancias que podrían excusar la práctica del canibalismo, Hook cree que Zenón no tendría en mente la de una ciudad sitiada, pues, según él, tal ejemplo no circularía por el mundo helenístico. Sin embargo, ya en Tucídides (II 70.1), encontramos el caso del asedio a Potidea, mencionado con cierta «asepsia», lo que puede 
estas prácticas serviría a Zenón para demostrar que, si se dan determinadas circunstancias, tales acciones no serían moralmente rechazables o, al menos, podrían ser disculpables ${ }^{38}$. Es interesante observar que, con esta referencia al canibalismo, Diógenes Laercio conecta otras afirmaciones como que el cinis-

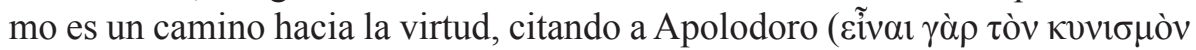

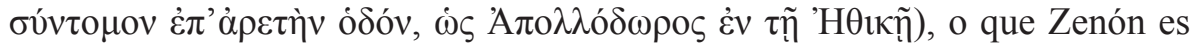
libre, pues puede actuar con autonomía, mientras que los demás son esclavos,

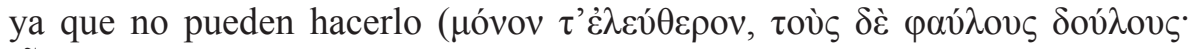

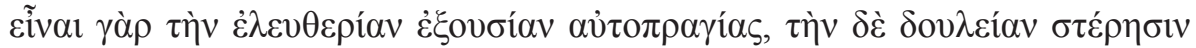
$\alpha u ̛ \tau o \pi \rho \alpha \gamma i ́ \alpha \varsigma)$. Tal vez la convenciones sociales esclavicen al ser humano hasta el punto de poner en peligro su vida; sin embargo, si uno se libra de ellas, puede, en situaciones límite, tomar las riendas de su propia existencia, es decir, salvar la vida, aunque para ello tenga que acudir a actos tan extremos como alimentarse de sus congéneres. En VII 188, Diógenes Laercio menciona algunas cosas dichas por el estoico Crisipo (281/78-208/05 a. C.) consideradas por algunos como torpes y obscenas, por ejemplo, sus referencias al incesto o la antropofagia, pues en el libro tercero de Sobre el Derecho (Пعрì

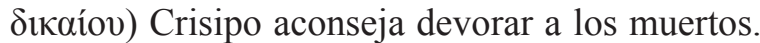

Ya hemos visto con relación a Diógenes que la tragedia griega, con las figuras míticas de Edipo o Tiestes como protagonistas, era el contexto en el que encontrarían expresión prácticas como el incesto o el canibalismo. Los autores trágicos utilizan dichas figuras como ejemplos moralmente reprobables, constituyendo además el límite entre la existencia o ausencia de civilización. La interesante tesis de Hook revela que la insistencia en estas prácticas por parte de los estoicos no es casual, sino que se explicaría por su deseo de distanciarse de las ideas expuestas por Platón en su República acerca de la imagen del tirano y de su alma, que busca satisfacer sus apetitos animales ${ }^{39}$. Platón — sigue argumentando Hook - escoge sin nombrarlos al Edipo y al Tiestes de la trage-

llevarnos a pensar que no fue ni el primero ni el último ejemplo de canibalismo en dichas circunstancias de asedio, que conocía el hombre griego.

${ }^{38}$ Hook 2005, pp. 17-18, citando a Vander Waerdt.

${ }^{39}$ A saber, la unión sexual con la madre, el asesinato y, parece interpretarse así, el caniba-

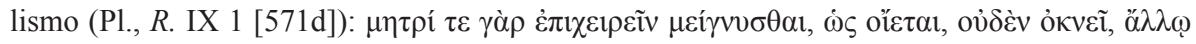

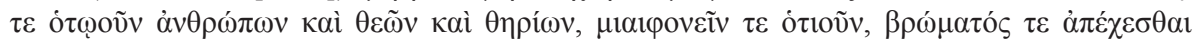
$\mu \eta \delta \varepsilon ́ v o \zeta$ «pues, según cree, [el alma] ante nada vacila, ni en su intento de cohabitar con su madre, ni con ningún otro ser humano o divino, ni con una bestia, ni en cometer asesinato, ni en abstenerse de alimento alguno». 
dia como representantes del alma del tirano. Tanto cínicos como estoicos admitirían que tan solo el sabio puede cometer tales acciones de manera justificada y bajo la presión de circunstancias especiales (Hook 2005, pp. 38-39).

Por su parte, los escépticos, por boca de Sexto Empírico, encontraban en las afirmaciones de Zenón o Crisipo una nueva oportunidad de atacar el pensamiento estoico: no podemos reprochar nada a los bárbaros que se alimentan de carne humana cuando los héroes de la mitología griega lo han hecho o los estoicos no lo consideran ilícito:

Y probar la carne humana es impío entre nosotros, pero en el conjunto de los pueblos bárbaros es indiferente. ¿Y qué se puede decir a los bárbaros cuando se afirma que incluso Tideo se comió los sesos de su enemigo y los estoicos afirman que no es inadecuado que uno se coma la carne de otros hombres y la suya propia? $?^{40}$.

Sin embargo, más adelante pone en duda que el fundador de la Estoa se atreviera a poner en práctica las «recomendaciones caníbales» que expone en su obra:

Y sin dilación también nos incita a comer carne humana en estos mismos textos. Así, por ejemplo, dice: «Si se cortase una parte de los vivos, útil como alimento, que no se entierre ni se tire de cualquier manera, sino que se consuma, de modo que se convierta en una nueva parte nuestra». Y en los libros Sobre el deber acerca del entierro de los padres, dice claramente: «Al morir los padres hay que celebrar los entierros más sencillos, en la idea de que el cuerpo no es nada para nosotros, como las uñas, los dientes o el cabello, y que, siendo así, no hemos de mostrarle solicitud o respeto. Por ello, si la carne es útil, se alimentarán de ella, como también de las partes propias, como, por ejemplo, convendría servirse de un pie amputado y de miembros semejantes; pero si es inútil, o bien tras enterrarla la dejarán o tras quemarla abandonarán sus cenizas o tras arrojarlas muy lejos no mostrarán interés alguno por ella, como las uñas o el cabello». Tales son cuantas cosas dicen frecuentemente los filósofos: lo que precisamente no se atreverían a cumplir, a no ser que viviesen con los cíclopes o los lestrigones ${ }^{41}$.

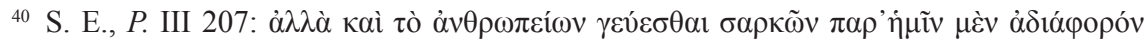

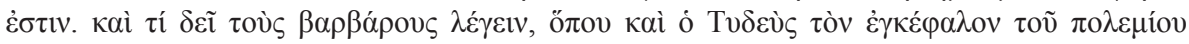

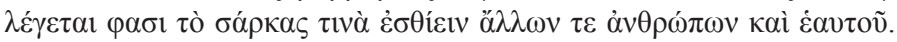

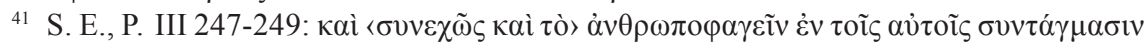

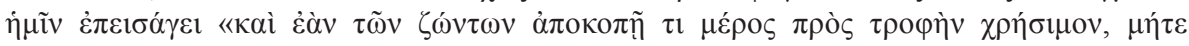


El estoicismo romano, personificado en Séneca, ejemplifica por medio de la tragedia las acciones que violentan gravemente las convenciones sociales. Pero Séneca no busca ahora moralizar sobre lo que va a tratar en su obra. Se ciñe a su mera presentación, siendo el espectador el que ha de sacar sus propias conclusiones. De este modo, Séneca en el Tiestes ${ }^{42}$, toda vez que las obras homónimas de Sófocles y Eurípides se han perdido ${ }^{43}$, muestra las consecuencias del más terrible acto de venganza, la expresión mayúscula del mal, protagonizada por Atreo: asesinar a unos inocentes niños y dárselos de comer a su padre.

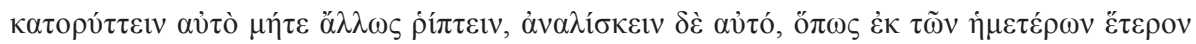

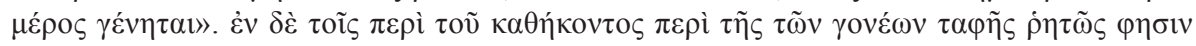

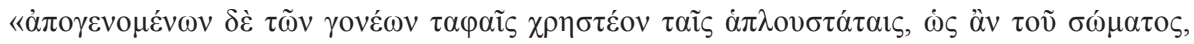

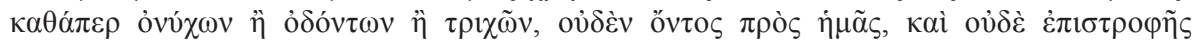

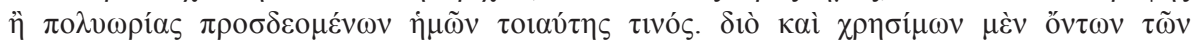

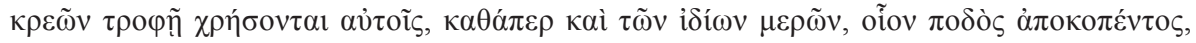

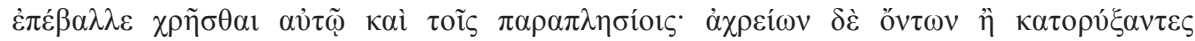

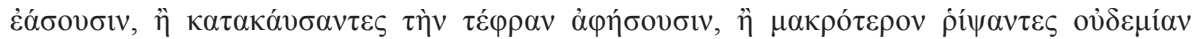

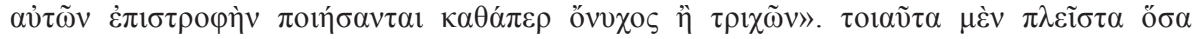

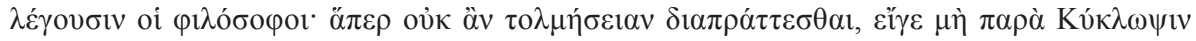
ì $\Lambda \alpha 1 \sigma \tau \rho v \gamma o ́ \sigma 1 ~ \pi 0 \lambda \imath \tau \varepsilon v ́ o เ v \tau o$.

Del mismo modo, siglos después, los cristianos, en la persona del obispo Teófilo de Antioquía (s. II), atacaban las enseñanzas tanto del estoicismo como del cinismo en las que se defendía la opción del canibalismo (Thphl. Ant., Autol. III 5 [Zeno Stoic. fr. 254 Arnim]). A su

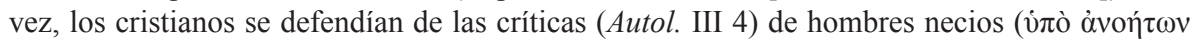

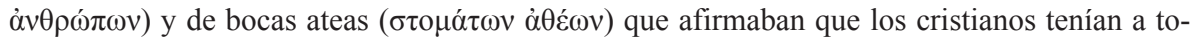
das sus mujeres en común y que, incluso, llegaban al incesto con sus hermanas; pero lo más impío e inhumano de todo era que les acusaban de comer carne humana ( $\sigma \alpha \rho \kappa \tilde{\omega} v \dot{\alpha} v \theta \rho \omega \pi i ́ v \omega v$

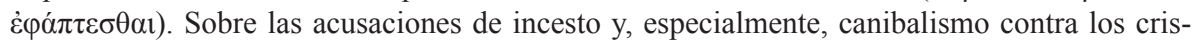
tianos, véase McGowan 1994, y también Wagemakers 2010, pp. 337-354.

${ }^{42}$ Para un comentario sobre la obra, v., por ejemplo, Herington 1989, pp. 575-580 y Viansino 1993, pp. 265-291 y 380-397.

${ }_{43}$ El tema tuvo que ser, sin embargo, muy popular, pues como señalan Herington (1989, p. 571, nn. 20-21) y Viansino (1993, pp. 267-268, de manera más detallada), la edición de Nauck $(T G F)$ contabiliza ocho autores griegos de un Tiestes y uno solo de un Atreo, mientras que la de Ribbeck $(T R F)$ menciona siete obras en latín — ocho con la de Séneca - tituladas Tiestes y cuatro Atreo. Aunque no sobrevive ninguna tragedia griega que trate directamente este episodio, Esquilo, en su Agamenón (1583-1601), por boca de Egisto, menciona la venganza de Atreo y el posterior banquete funesto (ßopòv ó $\sigma \omega \tau o v)$ y no se ahorra siquiera los

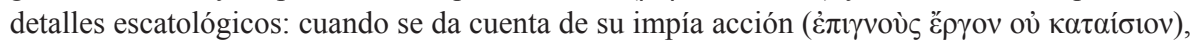

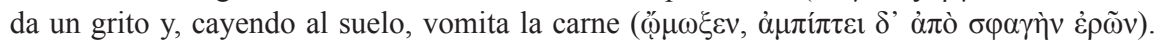


Cuando se entera de que su hermano Tiestes había cometido adulterio con su esposa Aérope, Atreo mata a sus sobrinos, los hijos de Tiestes, y tras trocearlos se los da de comer a su padre, al que había mandado llamar para supuestamente - reconciliarse tras la disputa por el trono de Tebas. Atreo corta los cadáveres de los hijos de Tiestes y solamente deja enteras las manos y las cabezas que le servirán para reconocerlos. Séneca, en consonancia con el tono de la obra, se para en otros detalles: por ejemplo, nos describe cómo una parte de la carne de los inocentes se cocina en la parrilla y otra se hierve en un caldero (vv. 759-775). La naturaleza insana del festín se refleja asimismo en el comportamiento y las maneras de Tiestes, que no se diferenciarían en exceso de la conducta de los comensales de una cena palaciega o de la alta sociedad romana quienes, embriagados por el vino, comerían atropelladamente:

nitet fluente madidus unguento comam / grauisque uino; saepe praeclusae cibum / tenuere fauces

Tiene él el pelo brillante, empapado en ungüentos que le gotean, y está pesado por el vino; a veces se cierra su garganta y detiene la comida... (Thy. 780782; trad. de Jesús Luque Moreno).

Ni siquiera nos libra de detalles de mal gusto que sirven para caracterizar al personaje e insistir en el horror de la escena ${ }^{44}$ :

resupinus ipse purpurae atque auro incubat, / uino grauatum fulciens laeua caput / eructat.

... él está echado boca arriba sobre la púrpura y el oro, apoyado en la mano izquierda su cabeza pesada por el vino ... Eructa... (Thy., 909-911; trad. de Jesús Luque Moreno).

Séneca, en su tragedia, nos dice que este hecho espantoso afecta incluso al curso del universo: el Sol no quiere asomar sobre el horizonte, mientras que los astros y constelaciones experimentan un «desplome apocalíptico» que «acaso lo provoque aquel festín horrendo» ${ }^{45}$. En la intervención del coro (Thy. 789-884) Séneca hace una descripción pormenorizada de los

\footnotetext{
${ }^{44}$ Cf., por ejemplo, en la épica, Verg., A. III 630-633, o Mart. III 82. 8.

45 Socas 2008, p. 381.
} 
prodigios que muestra el firmamento y el desorden de los signos zodiacales toda vez que el Sol huye ante la impiedad cometida ${ }^{46}$. De alguna manera, el orden cósmico se destruye: solitae mundi periere uices (813) y parece que el mundo se acaba: mundo secum pereunte mori (884). La naturaleza se horroriza ante una impiedad descomunal y hay señales que así lo indican, como el fuego que cocina los restos humanos y que parece no querer realizar su espantosa misión (inuitus ardet 770) o el humo que surge y que evidencia su nefasto origen, pues no asciende al cielo como lo haría el humo de un sacrificio piadoso, sino que, por el contrario, se condensa formando una horrenda nube (nube deformi 775). Es evidente que los dioses rechazan estas manifestaciones antropófagas, pero también es posible que sea así especialmente porque esta terrible acción recae sobre los propios hijos $^{47}$.

Según Socas, en este drama «los hombres se dirigen así miradas de carnívoros»; sin la buena fe, «la consecuencia segura es tener que comer antes de ser devorado, esto es, el canibalismo, que supone la renuncia a la condición humana y la maldad suprema» (Socas 2008, p. 382). Pero, además, en mi opinión, Atreo, dominado por una sádica locura, busca cumplir la venganza definitiva: eliminar por completo al adversario haciendo que él mismo, al devorar a su prole, termine con su linaje, con lo que la esencia vital que lo caracteriza se diluirá en sí mismo, y nadie podrá heredarla ${ }^{48}$. De algún modo, parece que busca compensar el incestuoso adulterio de Tiestes y su esposa que, por así decirlo, también ha diluido en el vientre de la mujer su propia semilla, confundiéndola con la de su hermano ${ }^{49}$. A ello hay que sumar una consecuencia práctica y tranquilizadora para quien ha ideado este terrible plan: evitar que en el futuro exista la posibilidad de continuar una espiral de venganza. Sin embargo, Atreo se equivoca: víctima de un terrible crimen

${ }^{46}$ Cf. J. Milton, Paradise Lost X 687-689: «At that tasted fruit / The Sun, as from Thyestean Banquet, turn'd / His course intended».

${ }^{47}$ Cuando Tiestes se entera del contenido de los manjares de su festín, comprende el significado de los prodigios que se producen en el mundo y entiende que ante tamaña monstruosidad hasta los dioses sientan repugnacia: Hoc est deos quod potuit, hoc egit diem / auersum in ortus (Thy. 1035-1036).

48 También leemos en el Antiguo Testamento (Leu. 26.29) cómo Dios anuncia a los israelitas los castigos que pueden sufrir por su desobediencia, como, por ejemplo, devorar a sus propios hijos e hijas.

${ }^{49}$ Cf. Viansino 1993, p. 266. 
cometido por un tirano, Tiestes responde con otro crimen en este loco carrusel de venganzas ${ }^{50}$.

Es evidente que Ovidio (Met. VI 650-665) ejerce una clara influencia en el desenlace final del acto $\mathrm{V}$ del Tiestes de Séneca, aunque los elementos de la escena presentan un orden distinto. Ovidio describe a Tereo sentado en el asiento de sus antepasados mientras amontona en su vientre sus propias entrañas (ipse sedens solio Tereus sublimis auito / uescitur inque suam sua uiscera congerit aluum 650-651). Seguidamente Tereo manda llamar a Itis. Procne culmina su venganza y le espeta: «iTienes dentro lo que deseas!» Tereo no entiende nada, pero Filomela, como una ménade de cabellos revueltos y ensangrentados, le arroja a su cuñado la cabeza del niño como prueba de su banquete caníbal:
'Ityn huc accersite!' dixit.
Dissimulare nequit crudelia gaudia Procne
iamque suae cupiens exsistere nuntia cladis
'intus habes, quem poscis' ait: circumspicit ille
atque, ubi sit, quaerit; quaerenti iterumque uocanti,
sicut erat sparsis furiali caede capillis,
prosiluit Ityosque caput Philomela cruentum
misit in ora patris $(652-658)^{51}$.

Tereo, lanzando grandes gritos, aparta violentamente la mesa e invoca a las deidades infernales; a su vez, desea abrirse el pecho y sacar de su interior a sus hijos, «horroroso festín» (Thracius ingenti mensas clamore repellit / uipereasque ciet Stygia de ualle sorores / et modo, si posset, reserato pectore diras / egerere inde dapes semesaque uiscera gestit 661-664). El padre termina llamándose a sí mismo «miserable sepulcro del hijo» (seque uocat bustum miserabile nati 665).

50 Siguiendo las indicaciones de un oráculo, Tiestes comete, esta vez conscientemente, otro de los pecados indecibles, el incesto: deja encinta a su hija Pelopia, y el hijo que engendrará, Egisto, acabará con la vida de Atreo y volverá a situar en el trono de Micenas a Tiestes (v. Ruiz de Elvira 1995, p. 170). Lo curioso es que Tiestes siempre arrastrará la etiqueta de caníbal, así como la culpa de un pecado cometido de manera involuntaria; sin embargo, el hecho de que cometiera incesto de manera consciente ha pasado casi completamente desapercibido.

51 «A Itis aquí traedme», dijo. / Disimular no puede sus crueles goces Procne, / y ya deseosa de erigirse en mensajera de su propia calamidad: / "Dentro tienes a quien reclamas", dice. Alrededor mira él / y dónde esté pregunta: mientras lo busca y de nuevo lo llama, /como ella estaba, asperjados de su sangría de furia sus cabellos / se abalanzó y de Itis la cabeza cruenta Filomela / le lanzó a la cara a su padre...» (trad. de Ana Pérez Vega). 
En Séneca, por su parte, cuando Tiestes ha terminado de comer, las entrañas se agitan en su interior como si protestaran ante el contenido del banquete (Quis hic tumultus uiscera exagitat mea? 999). Tiestes, que se teme lo peor, pide a su hermano que le devuelva a sus hijos (redde iam natos mihi! 997). Ahora es el momento que esperaba Atreo y, como Procne, tira de cruel ironía, mediante un juego de palabras: ¡Todo lo que de tus hijos queda lo tienes y todo lo que no queda lo tienes! (Quidquid e natis tuis / superest habes, quodcumque non superest habes. 1030-1031), enseñándole las cabezas y las manos de sus hijos (Expedi amplexus, pater; uenere. Natos ecquid agnoscis tuos? 1004-1005). La reacción es igualmente desaforada y, del mismo modo que Tereo, se acuerda de la laguna infernal (Agnosco fratrem. Sustines tantum nefas / gestare, Tellus? Non ad infernam Styga / tenebras mergis rupta...1006-1008). Asimismo, cuando Tiestes comprende la verdadera procedencia de las viandas, cual un Saturno arrepentido, busca de algún modo librarse del alimento ingerido, aunque sea abriéndose las entrañas con una espada (uoluuntur intus uiscera et clusum nefas / sine exitu luctatur et quaerit fugam. / Da frate, ensem (sanguinis multum mei / habet ille); ferro liberis detur uia 1041-1044). Más adelante se convence de que se ha convertido en la tumba de sus hijos (si natos pater / humare et igni tradere extremo uolo / ego sum cremandus 1090-1092) $)^{52}$.

52 En Heródoto encontramos dos episodios en los que los protagonistas agraviados por otro se desquitan de una manera semejante a como lo hace Atreo: los escitas con Ciaxares (I 73.3-6) y Astiages con Hárpago (I 119-129), donde la influencia del banquete de Atreo y Tiestes es evidente; v. Burkert 1983, pp. 108-109. Para otras versiones de este último episodio, v. Thphl. Ant., Autol. III 5; Sen., Dial. V 15. 1-2. Independientemente de la fiabilidad de los relatos de Heródoto, vemos que esta manera infame de vengar una afrenta no era exclusiva de la mitología. Más terrible es lo que cuentan algunas versiones consultadas por Plutarco (Cic. XLIX 2-4) acerca de la manera sádica en que Pomponia, la viuda de Quinto, el hermano de Cicerón, que también había sido asesinado durante las proscripciones, castigó a Filólogo, el liberto de Quinto que había traicionado a su esposo y a su cuñado: le obligó a cortarse pequeños trozos de carne, a asarlos y comérselos él mismo. Aunque Plutarco no puede asegurar que el hecho sucediera de verdad, él no deja de mencionarlo, pues, según Moles 2007, p. 35, es un episodio con valor moral: «the perpetrator of a dreadful betrayal is horribly punished». Pero también tiene valor literario, pues «a prime concern of ancient literture was to arouse emotion, and tragedy in particular aimed to arouse the emotions of pity and fear». Además, Plutarco cierra la obra con esta trágica y terrible historia que llevará «the pity and fear of ancient reader to unprecedents heights; and as an account of a peculiarly ghastly punishment it will satisfy his voracious appetite for the macabre». 
Séneca le da una vuelta de tuerca al episodio de Tiestes y Atreo y nos «regala» otro ejemplo de extrema crueldad vengativa (Dial. IV 33.4-6) para ejemplificar el carácter estoico. Calígula ha mandado ejecutar al hijo de un caballero romano al que invita luego a cenar. Esta vez, no se sirve la carne del vástago asesinado, pero el emperador prueba la resistencia del padre invitándole a beber (perdurauit miser, non aliter quam si fili sanguinem biberet), a mostrarse contento y a hacer libaciones. Incluso le obliga a besar su mano, manchada con la sangre de su hijo (Non dissimulauit iram et regis genua complexus funestam perfusamque cruore fili manum ad os suum rettulit, cenauit?). El anciano padre soporta todas las humillaciones que el cruel tirano le va infligiendo a lo largo del banquete, mostrando una actitud estoica hasta las últimas consecuencias. Finalmente, pasa la prueba del emperador y alcanza su premio: al menos conservará a su otro hijo. Esto explica la sobrecogedora continencia del anciano caballero.

3. Como hemos podido comprobar, no son pocas las menciones al acto caníbal en la literatura grecolatina. Desde un principio, en los mitos cosmogónicos encontramos episodios que - discutibles o no- contienen elementos relacionados con el canibalismo. Pero en la mitología destacan sobre todo los relatos en los que encontramos actos de canibalismo por venganza. El sentimiento de venganza es el mecanismo impulsor en varios episodios míticos, normalmente para hacer pagar una afrenta de tipo sexual (Atreo y Tiestes, Procne y Tereo). Los hijos del enemigo se convierten en el medio para llevar a cabo los planes de venganza. De este modo, el resultado que da satisfacción a dicho sentimiento es doble: cumple con su objetivo inmediato, pero también consigue evitar que la generación futura continúe el carrusel de la venganza. En otras ocasiones, es la divinidad la que, llevada por el deseo de venganza, empuja a un grupo (miniades, mujeres de Argos o básaros) a un estado de locura orgiástica que le lleva a perpetrar sacrificios humanos y actos de canibalismo. Esas referencias a posibles actos caníbales en un pasado mítico muy lejano, cuando el orden divino todavía no se ha impuesto en su plenitud, podrían explicar algunos vestigios rituales arcaicos que habrían sobrevivido en otras épocas, pero cuyo origen sería difícil de identificar en época clásica. En la Ilíada de Homero, curiosamente, las dos muertes más importantes de la narración - la de Patroclo, que impulsa el regreso de Aquiles, y la de Héctor, que sirve para que el hijo de Peleo vuelva a restablecer su honor entre las filas griegas - no solo siguen alimentando el deseo de 
venganza, sino que también encienden de nuevo sentimientos arrebatadores: Aquiles y Hécuba sienten una cólera tan profunda que desearían incluso devorar a los responsables de las muertes de sus seres más queridos. Tal vez sea la única forma de apagar la agonía que les devora en ese momento. Solo el episodio de Anfiarao, el único episodio épico donde se llega a cometer un acto de canibalismo, nos sirve para entender que la justicia de Zeus, representada por Atenea, rechaza dicho acto, que parece retrotraer a estadios primitivos de salvajismo.

En los fragmentos que sobreviven tanto de los órficos, como de los pitagóricos o de Empédocles, hay también numerosas referencias al canibalismo, consecuencia evidente de su creencia en la metempsicosis o reencarnación del alma de un cuerpo a otro, no solo humano, sino también animal, tras la muerte. La lógica de su doctrina lleva a la conclusión de que sacrificar animales y comer sus restos puede convertirse en un acto inevitable de canibalismo, incluso de los propios familiares. El consumo de carne retrotrae a un estadio anterior de injusticia, si no de maldad, donde el más fuerte se come al más débil; es un acto que rompe cualquier tipo de orden y armonía, llevando al ser humano al precipicio del salvajismo y la barbarie. Razón por la que los fundadores de estas doctrinas abogan por evitar el consumo de carne y propugnan alimentarse de lo que produce la tierra (los pitagóricos, incluso, llegan al extremo: defienden una dieta completamente vegetariana). Por ello, el abandono de las prácticas antropófagas, a veces facilitado por la labor de un personaje extraordinario, como por ejemplo Orfeo, simbolizaría el progreso. La imagen del tirano caníbal y sediento de sangre, utilizada por Platón, es un reflejo de ese primitivo estadio de iniquidad que las escuelas filosóficas anteriores han mencionado. Por su parte, los cínicos y los estoicos, representados en las figuras de personajes no solo extraordinarios, sino también excéntricos, muestran comprensión e incluso justifican de algún modo las prácticas caníbales, tal vez buscando llegar a los límites de las convenciones sociales y no tanto distanciarse de la sociedad a la que pertenecen (tesis de McGowan), como de las enseñanzas filosóficas más asentadas (tesis de Hook). Quebrantar la imposiciones sociales, incluido el hecho de comer carne humana, puede constituir no tanto un acto de salvaje rebeldía como de libertad individual.

Cierro el presente estudio con la figura de Tiestes, cuyo relato parece que alimentó la curiosidad morbosa de los antiguos. En la única tragedia homónima que ha sobrevivido, el autor, el estoico Séneca, reúne bastantes de los 
elementos que hemos comentado a lo largo del trabajo, siendo la referencia literaria más extensa al acto caníbal que ha llegado a nosotros, junto con el pasaje ovidiano de Procne y Tereo, de evidente influencia en la tragedia del autor cordobés. Como hemos visto en la mitología, la venganza impulsa el acto caníbal, pues Atreo, evidentemente influenciado por los «antecedentes» familiares (Tántalo y su gusto también por celebrar festines antropófagos), quiere cobrarse con creces la afrenta protagonizada por su hermano. Asimismo, en la tragedia de Séneca se da a entender la existencia de un todo interrelacionado que, de alguna manera, hemos visto en las distintas escuelas filosóficas (pitagóricos, Empédocles, cínicos), quienes, básicamente, creen en la existencia de una especie de alma, de un vínculo armonioso que traspasa a todos los seres vivos. Por ello, cuando se comete el macabro acto, la Naturaleza, que mantiene un delicado equilibrio, se revuelve, protesta ante la horrible enormidad de la acción. Por otra parte, Platón estaría de acuerdo en que Atreo se nos presenta como un aventajado alumno en la carrera por ser el más cruel tirano sediento de sangre, eso sí, dándosela de beber a su odiado hermano (vv. 914-917) —a Séneca no le debieron faltar modelos en los que inspirarse (Calígula, Nerón) - . Tiestes, por su parte, se convierte en figura arquetípica del caníbal y ni siquiera su ignorancia disculpa lo que ha hecho. Por ese motivo, no solo pide castigo para su hermano, sino también para él mismo. El mal absoluto se ha asentado sobre la Tierra y tan solo el supremo rey del cielo está capacitado para vengar no tanto la atrocidad cometida, como el caos en el que se ve envuelto el mundo, semejante al que existió en tiempos de los Gigantes, cuando todavía no existía la justicia divina, cuando imperaba la ley del más fuerte. Si los dioses no se conmueven ante estos hechos, que la noche siga cubriendo con sus tinieblas el más grande de los crímenes cometidos por el hombre: no es solo consumir carne y sangre humanas, es, sobre todo y ante todo, haber devorado carne de su carne y haber bebido sangre de su sangre.

\section{BiBLIOGRAFÍA}

Adrados, F. R. (trad.) 2000³: Aristófanes. Los Acarnienses. Los caballeros. Las Tesmoforias. La Asamblea de las Mujeres, Madrid.

Bernabé, A. 2009a: «El mito órfico de Dioniso y los Titanes», en Bernabé, A. y Casedesús, F. (eds.), Orfeo y la tradición órfica: un reencuentro, t. I, Madrid, pp. 591-607. 
Bernabé, A. 2009b: «Orfeo y el orfismo en la comedia griega», en Bernabé, A. y Casedesús, F. (eds.), Orfeo y la tradición órfica: un reencuentro, t. II, Madrid, pp. 1217-1238.

Bonnechère, P. 1994: Le sacrifice humain en Grèce ancienne, Atenas-Lieja.

Burkert, W. 1983: Homo necans: The Anthropology of Ancient Greek Sacrificial Ritual and Myths, Berkeley.

Casadesús Bordoy, F. 2009: «Orfismo y pitagorismo», en Bernabé, A. y Casedesús, F. (eds.), Orfeo y la tradición órfica: un reencuentro, t. II, Madrid, pp. 10531078.

Dodds, E. R. 1999: Los griegos y lo irracional, Madrid.

Fox, R. L. 2009: Héroes viajeros. Los griegos y sus mitos, Barcelona.

Henrichs, A. 1984: «Loss of Self, Suffering, Violence: The Modern View of Dionysus from Nietzsche to Girard», HSCPh 88, pp. 205-240.

Henrichs, A. 2000: «Drama and Dromena: Bloodshed, Violence, and Sacrificial Metaphor in Euripides», HSCPh 100, pp.173-188.

Herington, C. J. 1989 «Séneca el Joven», Kenney, E. J. y Clausen, W. v. (eds.), Historia de la literatura clásica. II. Literatura latina, Oxford, pp. 561-584.

Hook, B. S. 2005: «Oedipus and Thyestes among the Philosophers: Incest and Cannibalism in Plato, Diogenes, and Zeno», $C P h$ 100, pp. 17-40.

Jiménez San Cristóbal, A. I. 2009: «Los orfeotelestas y la vida órfica», en Bernabé, A. y Casedesús, F. (eds.), Orfeo y la tradición órfica: un reencuentro, t. I, Madrid, pp. 771-800.

Kilgour, M. 1990: From Communion to Cannibalism. An Anatomy of Metaphors of Incoporation, Princeton.

La Croce, E. et alii (trad.) 1979: Los filósofos presocráticos II, Madrid.

Luque Moreno, J. (trad.) 1980: Séneca. Tragedias II, Madrid.

McGowan, A. 1994: «Eating People: Accusations of Cannibalism against the Christians in the Second Century», JECS 2, pp. 413-442.

Megino, C. 2009: «Empédocles y el orfismo», en Bernabé, A. y Casedesús, F. (eds.), Orfeo y la tradición órfica: un reencuentro, t. II, Madrid, pp. 1105-1140.

Moles, J. L. 2007: Plutarch. The Life of Cicero, Eastbourne.

Nestle, W. 2010: Historia del espíritu griego, Barcelona.

Onians, R. B 1951: The Origins of European Thought, Cambridge.

Pérez Vega, A. 2002: Ovidio. Metamorfosis, Sevilla.

Renehan, R. 1981: «The Greek Anthropocentric View of Man», HSCPh 85, pp. 239259.

Ruiz de Elvira, A. 1995: Mitología Clásica, Madrid.

Russell, B. 1995: Historia de la filosofía occidental, Madrid.

Socas, F. 2008: Séneca. Cortesano y hombre de letras, Sevilla.

Viansino, G. 1993: Seneca, Teatro (vol. II), Milán. 
EL FENÓMENO DEL CANIBALISMO EN LAS FUENTES LITERARIAS 135

Wagemakers, B. 2010: «Incest, Infanticide, and Cannibalism: Anti-Christian Imputations in the Roman Empire», G\&R 57, pp. 337-354.

West, M. L. (ed.) 1997: Hesiod. Theogony, Oxford.

Fecha de recepción de la primera versión del artículo: 25/10/2011

Fecha de aceptación: 12/12/2012

Fecha de recepción de la versión definitiva: 14/01/2013 